\title{
Periodontal Pathogens in the Etiology of Pancreatic Cancer
}

\author{
Mesut Öğrendik \\ Division of Rheumatology, Department of Physical Medicine and Rehabilitation, \\ Uzunköprü State Hospital, Uzunköprü, Turkey
}

\section{Keywords}

Etiology $\cdot$ Pancreatic cancer $\cdot$ Periodontal pathogens

\begin{abstract}
Background: Pancreatic cancer is the fourth leading cause of cancer-related deaths worldwide. Chronic pancreatitis is frequently observed in patients with pancreatic cancer, and a significant relationship between orodigestive cancer-related deaths and chronic periodontitis has been detected. Porphyromonas gingivalis, Tannerella forsythia, and Treponema denticola, collectively called the Red complex, are the major pathogens responsible for chronic periodontitis and secrete peptidylarginine deiminase. Anti- $P$. gingivalis antibodies titers are higher in pancreatic cancer patients than in healthy subjects. Summary: This review examines the association between oral bacteria and the etiology of pancreatic cancer. Key Message: High rates of tumor suppressor gene $p 53$ mutations, particularly $p 53$ arginine mutations, were detected in pancreatic cancer patients. $K$-ras arginine mutations were detected in patients with pancreatic cancer. Oral bacteria peptidylarginine deiminases might lead to the $p 53$ and $K$-ras point mutations by degrading arginine. Practical Implications: Oral bacteria are likely to be responsible for the development of pancreatic cancer. If this hypothesis is true, it may reveal the real cause of pancreatic cancer, which is a fatal disease.

(C) 2016 S. Karger AG, Basel
\end{abstract}

\section{Introduction}

Pancreatic cancer is the fourth leading cause of cancer-related deaths worldwide [1] and causes approximately 8,000 deaths in the United Kingdom every year [2]. The rate of this cancer has been increasing in Western countries [3]. Chronic pancreatitis is frequently observed in patients with pancreatic cancer [4], and a significant relationship between orodigestive cancer-related deaths and chronic periodontitis has been detected [5]. 
Periodontal diseases are a group of disorders that affect the supporting tissues of the teeth. Periodontal diseases are common; for example, in a national survey in the United Kingdom, $79 \%$ of dentate adults had bleeding gums, $88 \%$ had calculus, and $69 \%$ had periodontal pockets, including $10 \%$ with deep pockets [6].

In periodontal diseases, the junctional epithelial tissue at the base of the gingival crevice migrates down the root of the tooth to form a periodontal pocket [6]. This movement is a direct result of the microorganisms themselves and the indirect but potentially damaging side effects of the host's inflammatory response to plaque accumulation. Individuals with periodontal disease have different predominant microflora than healthy individuals, but there is no single or unique pathogen associated with the disease. Most are gram-negative and obligately anaerobic, except for capnophilic microflora which are associated with localized juvenile periodontitis [6]. Although the microflora in periodontal disease are diverse, certain species are commonly found at sites undergoing tissue breakdown, including Porphyromonas gingivalis, Aggregatibacter actinomycetemcomitans, Tannerella forsythia, Prevotella intermedia, and Treponema denticola [6].

Among the gram-negative bacteria isolated in high numbers from sites affected by periodontal disease, $P$. gingivalis has been shown to have the greatest proteolytic activity and to be the most virulent species inoculated in animals in a simple pathogenicity test [6]. The majority of this proteolytic activity has been characterized as gingipain, an arginine-specific cysteine protease [6]. P. gingivalis, T. forsythia, and T. denticola, collectively called the Red complex, are the major pathogens responsible for chronic periodontitis and secrete peptidylarginine deiminase [6].

The study did not include human subjects, therefore ethical approval was not required.

\section{Periodontal Pathogens and Pancreatic Cancer}

It has been shown that the periodontal pathogens $P$. gingivalis and Fusobacterium nucleatum stimulate tumorigenesis and human oral tumor proliferation [7]. Michaud et al. [8] detected higher levels of antibodies formed against $P$. gingivalis in patients with pancreatic cancer than in healthy volunteers. Their multicenter study was performed on 405 pancreatic cancer cases and 416 matched controls. They observed a 2 -fold increase in pancreatic cancer among individuals who had high levels ( $>200 \mathrm{ng} / \mathrm{ml}$ ) of antibodies to the periodontal pathogen P. gingivalis ATTC 53978 compared with those with lower levels $(\leq 200 \mathrm{ng} / \mathrm{ml})$. It was the first study to examine antibodies to oral bacteria and the risk of pancreatic cancer. The findings suggest that individuals who have high levels of antibodies to P. gingivalis ATTC 53978 are at higher risk of pancreatic cancer.

\section{Mutations in Pancreatic Cancer}

High rates of tumor suppressor gene $p 53$ mutations, particularly $p 53$ arginine mutations, were detected in pancreatic cancer patients [9]. There is a close relationship between p53ArgPro mutations and gastrointestinal cancers, including pancreatic cancer [10].

K-ras codon 12 arginine mutations were detected in pancreatic cancer patients in one study and have been observed in others $[11,12]$. Point mutations at codon 12 of the $K$-ras gene have been observed in more than $75 \%$ of pancreatic cancer patients [13]. These mutations are considered a sign of poor prognosis [14]. The GTPase-activating protein arginine finger is crucial for the interaction of Ras [15]. 


\section{Conclusions}

Oral bacteria peptidylarginine deiminases might lead to $p 53$ and $K$-ras point mutations by degrading arginine. Oral bacteria are likely to be responsible for the development of pancreatic cancer. If this hypothesis is true, it may reveal the real cause of pancreatic cancer, which is a fatal disease.

\section{Disclosure Statement}

The author declares that he has no conflict of interest. This work received no funding.

\section{References}

1 Jemal A, Bray F, Center MM, Ferlay J, Ward E, Forman D: Global cancer statistics. CA Cancer J Clin 2011;61: 69-90.

2 Office for National Statistics: Cancer Statistics Registrations Series MB1. London, Office for National Statistics, 2011.

3 Boyle P, Hsieh CC, Maisonneuve P, La Vecchia C, Macfarlane GJ, Walker AM, Trichopoulos D: Epidemiology of pancreas cancer (1988). Int J Pancreatol 1989;5:327-346.

4 Michaud DS: Role of bacterial infections in pancreatic cancer. Carcinogenesis 2013;34:2193-2197.

5 Ahn J, Segers S, Hayes RB: Periodontal disease, Porphyromonas gingivalis serum antibody levels and orodigestive cancer mortality. Carcinogenesis 2012;33:1055-1058.

6 Marsh PD, Martin MV (eds): Oral Microbiology, ed 4. Bodmin, MPG Books Ltd, 2001.

7 Binder Gallimidi A, Fischman S, Revach B, Bulvik R, Maliutina A, Rubinstein AM, Nussbaum G, Elkin M: Periodontal pathogens Porphyromonas gingivalis and Fusobacterium nucleatum promote tumor progression in an oral-specific chemical carcinogenesis model. Oncotarget 2015;6:22613-22623.

8 Michaud DS, Izard J, Wilhelm-Benartzi CS, You DH, Grote VA, Tjønneland A, Dahm CC, Overvad K, Jenab M, Fedirko V, Boutron-Ruault MC, Clavel-Chapelon F, Racine A, Kaaks R, Boeing H, Foerster J, Trichopoulou A, Lagiou P, Trichopoulos D, Sacerdote C, Sieri S, Palli D, Tumino R, Panico S, Siersema PD, Peeters PH, Lund E, Barricarte A, Huerta JM, Molina-Montes E, Dorronsoro M, Quirós JR, Duell EJ, Ye W, Sund M, Lindkvist B, Johansen D, Khaw KT, Wareham N, Travis RC, Vineis P, Bueno-de-Mesquita HB, Riboli E: Plasma antibodies to oral bacteria and risk of pancreatic cancer in a large European prospective cohort study. Gut 2013;62:17641770.

9 Barton CM, Staddon SL, Hughes CM, Hall PA, O’Sullivan C, Klöppel G, Theis B, Russell RC, Neoptolemos J, Williamson RC, et al: Abnormalities of the p53 tumour suppressor gene in human pancreatic cancer. Br J Cancer 1991;64:1076-1082.

10 Liu L, Wang K, Zhu ZM, Shao JH: Associations between P53 Arg72Pro and development of digestive tract cancers: a meta-analysis. Arch Med Res 2011;42:60-69.

11 Prassolov VS, Sakamoto H, Nishimura S, Terada M, Sugimura T: Activation of c-Ki-ras gene in human pancreatic cancer. Jpn J Cancer Res 1985;76:792-795.

12 Evans T, Faircloth M, Deery A, Thomas V, Turner A, Dalgleish A: Analysis of K-ras gene mutations in human pancreatic cancer cell lines and in bile samples from patients with pancreatic and biliary cancers. Oncol Rep 1997;4:1373-1381.

13 Watanabe H, Miyagi C, Yamaguchi Y, Satomura Y, Ohta H, Motoo Y, Okai T, Yoshimura T, Tsuji Y, Sawabu N: Detection of K-ras point mutations at codon 12 in pancreatic juice for the diagnosis of pancreatic cancer by hybridization protection assay: a simple method for the determination of the types of point mutation. Jpn J Cancer Res 1996;87:466-474.

14 Sinn BV, Striefler JK, Rudl MA, Lehmann A, Bahra M, Denkert C, Sinn M, Stieler J, Klauschen F, Budczies J, Weichert W, Stenzinger A, Kamphues C, Dietel M, Riess H: KRAS mutations in codon 12 or 13 are associated with worse prognosis in pancreatic ductal adenocarcinoma. Pancreas 2014;43:578-583.

15 Prior IA, Lewis PD, Mattos C: A comprehensive survey of Ras mutations in cancer. Cancer Res 2012;72:24572467. 